\title{
The Brazilian slums hiring their own doctors to fight covid-19
}

\author{
In the absence of help from public authorities, the residents of one of Brazil's largest slums are \\ mobilising themselves to contain the spread of covid-19, writes Rodrigo de Oliveira Andrade
}

\section{Rodrigo de Oliveira Andrade}

São Paulo

Like many people around the world just now, those living in the São Paulo neighbourhood of Paraisópolis are terrified of covid-19. But, with a national president in denial of the pandemic and authorities that would rather forget that the slums even exist, these residents couldn't wait for help. So, in March 2020, together with a non-profit organisation, they decided to help themselves.

They hired a private medical service with three ambulances equipped with an intensive care unit, as well as two doctors, two nurses, drivers, and first aid workers. The medical team takes turns on 24 hour shifts to attend to people with suspected coronavirus infection, to help stop the spread.

"We knew that slums would be hit the worst as Brazil started registering the first cases of covid-19," says Daniel Cavaretti, national coordinator of G10 Favelas, a joint project involving community leaders from several slums in Brazil. "We feared that people would despair and run to hospitals and local health centres, which are not prepared for it."

\section{The most vulnerable}

Brazil registered its first case of covid-19 on 25 February in a private hospital in Morumbi, a wealthy São Paulo neighbourhood close to Paraisópolis. ${ }^{1}$ Weeks later, the country's Ministry of Health started advising people to stay at home and avoid crowds-despite the right wing president, Jair Bolsonaro, continuing to dismiss the virus as "a little flu" or a media "fantasy." ${ }^{2} \mathrm{He}$ has since fired the health minister after weeks of disagreement over the handling of the pandemic.

State governments have closed schools, universities, shops, and restaurants. Public agencies have reduced their service hours, while many companies have sent their employees to work from home. The advice is the same as anywhere in the world-staying at home, social distancing, washing hands—but it's problematic in crowded Paraisópolis.
"It turns out that it's almost impossible to follow all these guidelines when you live in a slum," says Celso Athayde, one of the founders of Cufa, a national organisation representing slum residents. He tells The BMJ, "The government asks people to stay at home and reinforce personal hygiene without realising that such care comes up against the lack of water in precarious houses, where families live huddled together."

Yuri Macedo, a professor at the Federal University of Espírito Santo's Afro-Brazilian Studies Center, says that "slums' socioeconomic characteristics are not being taken into account by countries' health authorities in their strategies to contain the coronavirus."

Paraisópolis has an estimated population of 120 000. Unlike their rich neighbours in luxury buildings and high walled mansions, most of its residents live together in tiny, unventilated, poorly lit houses close to each other. "There is no way to keep social isolation when you have to share three rooms with six, seven other people who often go out to look for a job or to buy some food," Athayde explains.

Paulo Buss, a physician at the Oswaldo Cruz Foundation's Center for International Health Relations in Rio de Janeiro, says, "The packed living conditions and poor sanitation have made Brazilian's slums vulnerable to diseases of many sorts for decades, and it's no different with covid-19."

In the absence of leadership, the slum residents are leading themselves.

\section{Private healthcare}

G10 Favelas is run by leaders of the residents' associations in Brazil's biggest slums. Through donations of money, equipment, and services from various Brazilian companies, it aims to boost entrepreneurship among slum residents while stimulating the local economy by running educational, sporting, and cultural initiatives. 
Running a healthcare system is far outside G10's original remit but one born of necessity, given the dangers of the coronavirus and its potentially severe impact on the residents, both health-wise and economically. Along with the Paraisópolis residents' association, G10 Favelas started by building a network of 400 volunteers, each responsible for a region with nearly 50 families.

"They have four main tasks," Cavaretti explains. "One is to ensure that people stay at home and keep social isolation." The volunteers are also responsible for distributing food and cleaning products received by donation. They also monitor families through social media tools and call the medical team whenever someone presents with covid-19 symptoms, such as fever and cough.

The idea of hiring a private medical service came up in late March after talks with the residents' association. The group hired a private medical company at a daily cost of $\mathrm{R} \$ 6000$ (£920; $€ 1040 ;$ US\$1130). Some of the money that pays the medical team comes from donations; G10 Favelas declined to say where the rest of the money comes from.

The medical team screens people in their homes, to avoid them using public transport to go to a hospital. Cavaretti says, "If somebody needs more care or if they present symptoms of covid-19, we use the ambulance to take them to the hospital."

It's not always that simple, however. Most Paraisópolis residents live in houses in narrow, crooked alleyways, where the ambulance can't pass through. "In these cases we have to use stretchers to carry people through," Alexandre Santos, a first aid worker in Paraisópolis, tells The BMJ.

Luiz Carlos Barbosa, one of the neighbourhood's doctors, says, "The lack of infrastructure has been the main challenge. We're not trained to work in these conditions at medical school." He tells The BMJ that it's been hard to attend to people in such vulnerable conditions, living in makeshift housing without access to water and basic sanitation. "We're doing our best," he says, "but I'm not sure if it will be enough here."

Barbosa adds that 200 people have already presented typical symptoms of covid-19 in Paraisópolis and have been referred to hospitals in the region-but they are still waiting for the test results. At least 15 have been confirmed with coronavirus, and another eight have died from the disease. Those with severe symptoms are taken to an intensive care unit, while those with mild symptoms are isolated in their homes, and their family members are moved temporarily to friends' or relatives' houses nearby.

Given the increasing number of cases, G10 Favelas has started negotiating with São Paulo's Department of Health to build a field hospital in two public schools that have been closed during the outbreak. Cavaretti explains, "The idea is to take people without life threatening symptoms to this place and avoid transmitting the virus to their families."

\section{Business as usual}

G10 Favelas aims to roll out the Paraisópolis model in Brazil's other slums - the biggest being Rocinha in Rio de Janeiro, which at the time of writing has registered 35 covid-19 infections and two deaths.

Poor populations that normally lack access to health services tend to be even more vulnerable in times of crisis. ${ }^{3}$ The Paraisópolis medical team is finding that the model it has adopted allows it not only to treat covid-19 but to diagnose other diseases that commonly affect people living in slums, such as tuberculosis and syphilis. Santos comments, "Many of them did not even know they had some serious health problems, such as high blood pressure and diabetes."

Comorbidities have implications for a patient's risk of contracting coronavirus, and they also reflect the wider problems faced by slum residents. A survey by the Locomotiva Institute and Data Favela of 1808 people from 69 of Brazil's slums found that $47 \%$ of slum houses had no running water and that almost $15 \%$ of families did not have enough money to buy soap.

Cufa, the national organisation, works with companies to gather everyday basic items and distribute them to 5000 slums scattered throughout the country. Athayde says, "We have already raised 600 tons of food, toiletries, and cleaning products." This has a dual purpose. The idea is to set up distribution centres also staffed with medical teams to check anyone who presents covid-19-like symptoms and to inform people about the disease as they visit.

Since the beginning of the pandemic almost $53 \%$ of Brazil's slum residents have lost half of their income, and almost $60 \%$ do not have enough stocked food for more than a week. Buss tells The BMJ, "The coronavirus's socioeconomic effects reached Brazil's slums before the virus itself."

As a result, the movement of people on slum streets remains high, as people continue to work. In Paraisópolis, unlike the rest of locked-down São Paulo, most bars and shops remain open as people need to earn money for basic living expenses. The situation would please President Bolsonaro, who continues to tell his citizens to get back to work rather than self-isolate. ${ }^{4}$

Competing interests: I have read and understood BMJ policy on declaration of interests and have no relevant interests to declare.

Provenance and peer review: Commissioned; not externally peer reviewed.

1 Rodriguez-Morales AJ, Gallego V, Escalera-Antezana JP, etal . COVID-19 in Latin America: The implications of the first confirmed case in Brazil. Travel Med Infect Dis 2020;101613 10.1016/j.tmaid.2020.101613 32126292

2 Phillips T. Bolsonaro says he "wouldn't feel anything" if infected with Covid-19 and attacks state lockdowns. 2020. https://www.theguardian.com/world/2020/mar/25/bolsonaro-brazilwouldnt-feel-anything-covid-19-attack-state-lockdowns.

3 Ahmen F. Why inequality could spread COVID-19. Lancet Publ Health 2020:1-1.

4 Coletta RD. Bolsonaro criticizes the closure of schools, attacks governors and blames the media in televised statement. 2020. https://www1.folha.uol.com.br/internacional/en/ brazil/2020/03/bolsonaro-criticizes-the-closure-of-schools-attacks-governors-and-blamesthe-media-in-televised-statement.shtml.

Published by the BMJ Publishing Group Limited. For permission to use (where not already granted under a licence) please go to http://group.bmj.com/group/rights-licensing/ permissions 